Rozanov, A. Yu., Missarzhevsky, V. V;, Volkova, N. A., Voronova, L. G., Krylov, I. N., Keller, B. M., Korolyuk, I. K., Lendzion, K., Michniak, P., Pykhova, N. G. \& Sidorov, A. D. 1969: Tommotian stage and the Cambrian lower boundary problem. Trudy Geol. Inst. Akad. Nauk. SSSR 206, 380 pp. (in Russian).

Schopf, W. 1968: Microflora of the Bitter Springs formation, late Precambrian, Central Australia. J. Paleont. 42. 651-688.

Troelsen, J. C. 1956: The Cambrian of North Greenland and Ellesmere Island. In El sistema Cambrico, su paleogeografía y el problema de su base. 20 Congr. geol. inst. Mêxico. Symp. 3(1), 71-90.

\title{
Late Ordovician and early Silurian stratigraphy of Washington Land, western North Greenland
}

\author{
John S. Peel and John M. Hurst
}

This paper revises the stratigraphy of a conspicuous sequence of generally cliff-forming limestones which spans the Ordovician - Silurian boundary in Washington Land, western North Greenland (fig. 4). The strata are referred to the Morris Bugt Group, formally proposed here. Four constituent formations are recognised (fig. 5), three of which have been previously described. However, the relevant sections were originally examined by Lauge Koch under arduous conditions and the passage of more than half a century has inevitably left its mark. It is not proposed to offer a full description of all the rock units at this time. The uppermost formation, the Aleqatsiaq Fjord Formation, is described by Hurst (in press), the three older formations will be discussed fully at a later date.

The names of two of the formations, the Gonioceras Bay and Cape Calhoun Formations, are particularly well known to Ordovician stratigraphers and palaeontologists through the monographic study of their faunas by Troedsson $(1926,1928)$. However, as acknowledged by Koch (1929b), much of this material was collected from talus, so that the precise derivation of individual specimens is unknown. The present lithostratigraphic revision is a first step in an attempt to rectify this problem. The fourth formation, the Troedsson Cliff Formation, of Koch (1929a, b) has been only rarely employed since its rather uncertain proposal. However, this name is used in order to simplify some of the problems arising out of revising the often rather incomplete stratigraphy of previous workers.

A fifth formation name has previously been used, namely the Wright Bay Formation of Teichert (1937). However, the recommendations of Troelsen (1950) concerning the abandonment of this unit are followed, and the term is not employed.

The Gonioceras Bay Formation, as used here, corresponds closely to the usage of Troedsson (1928) and Koch (1929 a, b). The Troedsson Cliff Formation is enlarged from Koch's use to include part of the Cape Calhoun Formation, as defined by Troedsson and Koch. The latter formation is greatly restricted, but as a consequence becomes a much more 


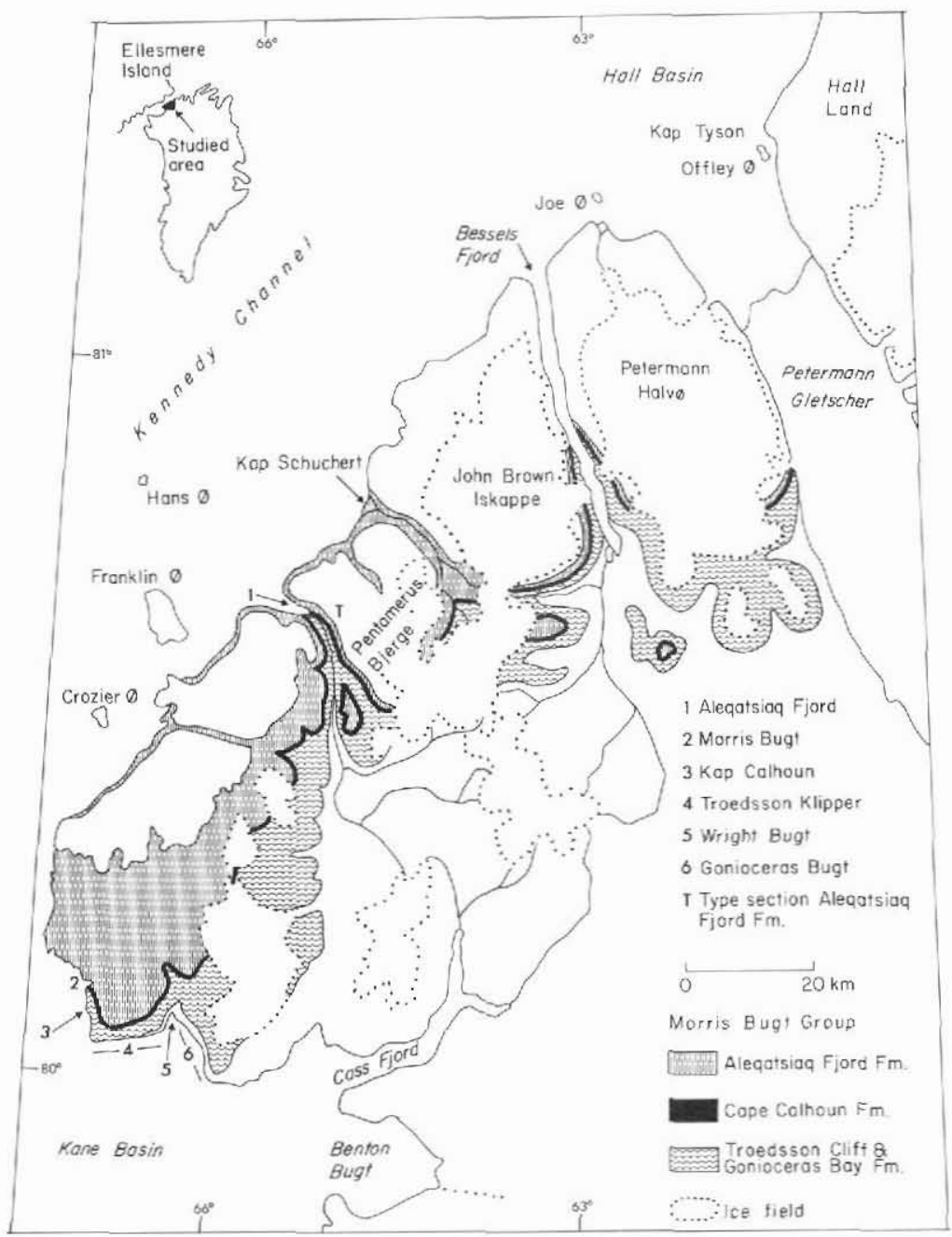

Fig. 4. Geological sketch map of Washington Land showing the distribution of the Morris Bugt Group and its component formations.

readily recognisable lithostratigraphic unit. The Aleqatsiaq Fjord Formation provides a link between previously described Ordovician and Silurian nomenclature (summarised by Koch, 1929a, and Hurst, in press). A correlation with previous stratigraphic schemes is presented in fig. 5. 

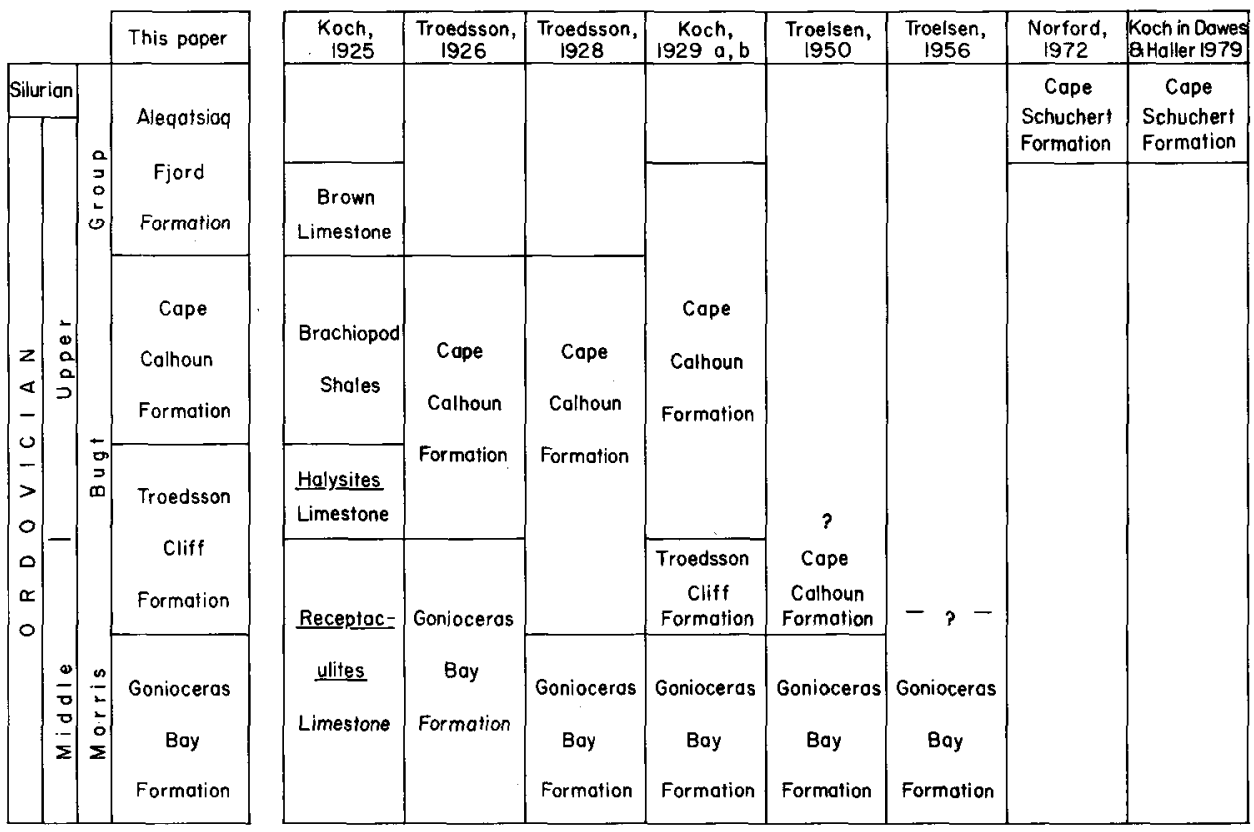

Fig. 5. Lithostratigraphic schemes for the Middle and Upper Ordovician rocks of Washington Land.

\section{Morris Bugt Group \\ new group}

Name. After the bay Morris Bugt, south-western Washington Land (fig. 4).

Type area. Rocks forming the group are excellently exposed in vertical cliffs extending from Morris Bugt in the west, to Gonioceras Bugt in the east (fig. 4).

Lithology. Mottled, nodular bedded, massively weathering brownish grey lime mudstones of the Gonioceras Bay Formation form the basal unit of the group. These are followed by alternating rubbly and more massive weathering silty lime mudstones of the Troedsson Cliff Formation. Recessive, thin bedded skeletal lime mudstones with thin greenish shale interbeds of the Cape Calhoun Formation overlie the Troedsson Cliff Formation. The section is completed by mottled, massive to nodular bedded, greyish brown, partly dolomitised lime mudstones and wackestones of the Aleqatsiaq Fjord Formation.

Thickness. The maximum observed thickness is about $760 \mathrm{~m}$.

Boundaries. The group conformably overlies the Cape Webster Formation throughout Washington Land. In the western part of Washington Land, it is conformably overlain by the Kap Constitution Group, while in central and northern Washington Land the overlying unit is the Washington Land Group (Hurst, in press). 
Distribution. The Morris Bugt Group outcrops to the north and west of Cass Fjord, to southern Bessels Fjord and Petermann Gletscher, in Washington Land, and eastward to Hall Land and, eventually, Wulff Land (Hurst \& Peel, 1979).

Geological Age. Late middle Ordovician (Black River) to early Silurian (late Lower Llandovery).

Subdivision. The Morris Bugt Group is subdivided into four formations; Gonioceras Bay Formation (70-80 m), Troedsson Cliff Formation (240-250 m), Cape Calhoun Formation $(65-70 \mathrm{~m})$ and Aleqatsiaq Fjord Formation $(250-360 \mathrm{~m})$, in ascending order.

\section{Gonioceras Bay Formation}

Name. After Gonioceras Bay, the Gonioceras Bugt of present use (fig. 4).

History. This name was first employed by Troedsson (1926). Koch (1929a) attributed authorship to himself in 1921, but this date relates to his field observations of the strata. Modifications in usage have been proposed by Troedsson (1928), Koch (1929b) and Troelsen $(1950,1956)$. The definition employed here is essentially that of these authors, although Troelsen (1956) suggested an extension of the formation upward which is not followed here.

Type locality. Gonioceras Bugt (fig. 4).

Thickness. Approximately $70-80 \mathrm{~m}$.

Lithology. The formation is composed of dark brownish weathering, brown-grey lime mudstones which are mottled, nodular, and massive weathering. Bedding joints are closely spaced near the base of the formation $(5-25 \mathrm{~cm})$ but become widely separated $(2-4 \mathrm{~m})$ above. Black coated stylolites are common.

Fauna and age. Troedsson (1926, 1928), Koch (1929b) and Troelsen (1950) have described and discussed the fauna of the Gonioceras Bay Formation. It is of late Middle Ordovician, probably Black River, age.

Boundaries. Uppermost beds of the Cape Webster Formation are interdigitated with lime mudstones of Gonioceras Bay Formation lithology. The latter formation is conformably overlain by the Troedsson Cliff Formation.

Distribution. Western and northern Washington Land. The formation has been traced eastward to Wulff Land (Hurst \& Peel, 1979). 


\section{Troedsson Cliff Formation}

Name. After Troedsson Cliffs, the Troedsson Klipper of present use (fig. 4).

History. The name was first employed by Koch (1929b), although Troelsen $(1950,1956)$ discontinued its use. In its present, redefined sense, the Troedsson Cliff Formation contains Koch's original formation of the same name, but is extended to include the so-called Halysites limestone which Troedsson (1926, 1928 ) and Koch (1929a, b) previously referred to the Cape Calhoun Formation.

Type locality. Koch (1929a) gave the type locality as the cliffs between Morris Bugt and Kap Calhoun (fig. 4).

Thickness. Approximately 240-250 m.

Lithology. In detail, the lime mudstones of the Troedsson Cliff Formation are quite similar to the underlying Gonioceras Bay Formation, although fresh surfaces tend to be grey. The two formations are principally separated on bedding and weathering phenomena. The Troedsson Cliff Formation typically consists of an alternation of $c .1 \mathrm{~m}$ thick nodular, rubbly weathering, rather recessive beds and nodular, massive and more prominent beds.

Fauna and age. Koch (1929b) could give little account of the fauna of his original Troedsson Cliff Formation other than to say that it contained abundant Receptaculites and Maclurites. Much of the fauna described by Troedsson $(1926,1928)$ from the Cape Calhoun Formation appears to be derived from the Halysites limestone, now a part of the Troedsson Cliff Formation. However, the origin of most of this material is so speculative that no meaningful assignment to specific rock units can be attempted. Field work in 1976-77 produced large collections af well preserved, but mainly undetermined fossils, mainly molluscs and corals. Gonioceras, Batostoma and Labyrinthites suggestive of a late Middle Ordovician (Black River) age are particularly common just above the junction with the underlying Gonioceras Bay Formation.

Boundaries. The Troedsson Cliff Formation is apparently conformable with both the underlying Gonioceras Bay Formation and the overlying Cape Calhoun Formation.

Distribution. Western and northern Washington Land. The formation has been tentatively traced eastward as far as Wulff Land (Hurst \& Peel, 1979).

\section{Cape Calhoun Formation}

Name. After Cape Calhoun, the Kap Calhoun of present usage (fig. 4).

History. This name was first published by Troedsson (1926), although Koch 1929a), in recording the date of his field observations, attributed authorship to himself in 1921. Revisions have been proposed by Troedsson (1928), Koch (1929b) and Troelsen $(1950,1956)$. The much restricted Cape Calhoun 
Formation employed here corresponds to the Leptaena beds of Koch (1925). The underlying Halysites limestone of Koch is referred to the Troedsson Cliff Formation (see above). The overlying brown limestone of Koch is now assigned to the Aleqatsiaq Fjord Formation.

Type locality. Kap Calhoun.

Thickness. $65-70 \mathrm{~m}$.

Lithology. This characteristically greenish weathering, recessive interval between the more prominent Troedsson Cliff and Aleqatsiaq Fjord Formations is a conspicuous mapping horizon in western North Greenland. Pale grey or greenish grey, nodular lime mudstones with green shaly partings predominate. Decrease in the shale component produces benches of more resistant lime mudstone and wackestone near the middle and top of the formation.

Fauna and age. The fauna, with its rich association of corals and molluscs, appears similar to that of the uppermost beds of the underlying Troedsson Cliff Formation. Many of the Cape Calhoun species described by Troedsson $(1926,1928)$ undoubtedly were derived from this horizon, although it is not possible to be more specific. A general late Ordovician age is indicated.

Boundaries. The Cape Calhoun Formation is conformable with the underlying Troedsson Cliff Formation and the overlying Aleqatsiaq Fjord Formation.

Distribution. Western and northern Washington Land. The formation has been recognised as far eastward as Wulff Land (Hurst \& Peel, 1979).

\section{Aleqatsiaq Fjord Formation}

Name. After Aleqatsiaq Fjord on the north-west coast of Washington Land (fig. 4). On earlier maps the fjord is spelt as Alakratiak.

History. Strata which are now referred to the Aleqatsiaq Fjord Formation were probably included by Koch (1920) in his Upper Silurian Coral Limestone and by Koch (1929a) in his Cape Calhoun Formation and Cape Schuchert Formation. Norford (1972) referred strata belonging to the Aleqatsiaq Fjord Formation at Kap Schuchert (fig. 4), to the Cape Schuchert Formation (Hurst, in press).

Type section. On the south-western slopes of the Pentamerus Bjerge, on the east side of the north-south valley from the head of the fjord (fig. 4).

Thickness. From 250 to $360 \mathrm{~m}$.

Lithology. The formation is composed mainly of lime mudstones and wackestones which weather to a nodular dark grey-brown and mottled yellowish appearance. The upper parts of the formation are often chertified and with thin shale films. Pervasive dolomitisation occurs throughout. 
Fauna and age. Generally the formation is not very fossiliferous, the fauna is mainly represented by scattered actinoceratid cephalopods, tabulate corals and stromatoporoids. A late Ordovician to early Silurian (Lower Llandovery) age is indicated.

Boundaries. The Aleqatsiaq Fjord Formation is conformable with the underlying Cape Calhoun Formation and with numerous overlying formations of both the Kap Constitution and Washington Land Groups (Hurst, in press).

Distribution. Western and northern Washington Land. The formation has been recognised as far eastwards as Wulff Land (Hurst \& Peel, 1979).

Troelsen, J. C. 1956: Groenland. In Lexique Stratigraphique International 1 (1a), 116 pp. Paris: C.N.R.S.

\section{References}

Dawes, P. R. \& Haller, J. 1979: Historical aspects in the geological investigations of northern Greenland. Meddr. Grønland 200(4), $38 \mathrm{pp}$.

Hurst, J. M. in press: Silurian stratigraphy and facies distribution in Washington Land and western Hall Land, North Greenland. Bull. Grønlands geol. Unders.

Hurst, J. M. \& Peel, J. S. 1979: Late Proterozoic(?) to Silurian stratigraphy of southern Wulff Land, North Greenland. Rapp. Grønlands geol. Unders. 91, 37-56.

Koch, L. 1920: Stratigraphy of Northwest Greenland. Meddr dansk geol. Foren. 5(17), 78 pp.

Koch, L. 1925: The geology of North Greenland. Amer. J. Sci. (5), 9, 271-285.

Koch, L. 1929a: Stratigraphy of Greenland. Meddr Grønland 73(2), 2, 205-320.

Koch, L. 1929b: The geology of the south coast of Washington Land. Meddr Grønland 73 (1), 1, $39 \mathrm{pp}$.

Norford, B. S. 1972: Silurian stratigraphic sections at Kap Tyson, Offley $\emptyset$ and Kap Schuchert, Northwestern Greenland. Meddr Grønland 195(2), $40 \mathrm{pp}$.

Teichert, C. 1937: A new Ordovician fauna from Washington Land, North Greenland. Meddr Grønland 119(1), $65 \mathrm{pp}$.

Troedsson, G. T. 1926: On the Middle and Upper Ordovician faunas of northern Greenland. I. Cephalopods. Meddr Grønland 71, 1-157.

Troedsson, G. T. 1928: On the Middle and Upper Ordovician faunas of northern Greenland. II. Meddr Grønland 72(1), 1, $197 \mathrm{pp}$.

Troelsen, J. C. 1950: Contributions on the geology of Northwest Greenland, Ellesmere Island and Axel Heiberg Island. Meddr Grønland 149(7), 29 pp.

Troelsen, J. C. 1956: Groenland. In Lexique Stratigraphique International 1 (1a), 116 pp. Paris. C.N. R.S.

\section{Acritarchs from the Proterozoic Thule Group, North-West Greenland}

\section{Gonzalo Vidal and Peter R. Dawes}

A thick sequence of Proterozoic sedimentary and volcanic rocks (the Thule Group), penetrated in part by basic minor intrusions, characterises the Thule district of North-West Greenland (fig. 6). These strata, overlying the Greenland Shield with profound unconfor- 